but no less interesting are the evidences of the Maya architect's methods of construction. Stairways and vaulted chambers, columns and platforms, and enormous substructures are eloquent of the skill of these vanished people.

The Chichen Itzá project of the Carnegie Institution had devoted four field seasons of some four and a half months each to work on the Warriors when the present volume was written. Work has been under the direction of Dr. Sylvanus G. Morley throughout, who not only planned but also directed operations at Chichen. During the last twenty years, he has devoted himself to the Maya problem. and valuable results have been exemplified in his publications, as well as in the standing monument of the field work in Yucatan.

Few regions equal this strange promontory of the New World in opportunity for archæological investigation. The surface has only been scratched. Individuals and institutions able to share in the unravelling of problems in Yucatan, a chapter of the history of mankind, are to be envied.

\title{
Obituary.
}

Prof. Percy Groom, M.B.E., F.R.S.

THROUGH the death of Prof. Percy Groom, which occurred at Gerrard's Cross on Sept. 16, there has passed away a man with an outlook and interests somewhat exceptional in the senior ranks of British botanists. He was born on Sept. 12, 1865, and entered Mason College, Birmingham, as a student, from which he passed to Cambridge on being elected to an exhibition at Trinity College. He obtained a first class in Part I. and a second in Part II. of the Tripos in 1887, taking botany as his principal subject. Afterwards he was elected to a Frank Smart studentship in botany at Caius College.

During his student life Groom studied for a time at the University of Bonn, where he enjoyed the friendship of the botanists, headed by the eminent Prof. Strasburger, who were making that university the Mecca of so many of the English-speaking followers of the science. He owed much to A. F. W. Schimper, and a delightful appreciation of that gifted man appears as a foreword to the translation of Schimper's "Plant Geography", revised by Bayley Balfour and himself, which was published by the Clarendon Press in 1903 . In 1889 he was appointed to the professorship of botany and arboriculture at the Imperial College of Whampoa, in China, and it was doubtless largely owing to this that he was led to turn his attention to the study of trees, and thence to their diseases and economic products, on which he largely concentrated his attention in after years.

On returning to England in 1892, Groom settled for some years in Oxford, migrating to Edinburgh in 1898 to take charge of the classes in plantphysiology under Prof. Bayley Balfour. His stay there was short, as he was appointed in the following year to the headship of the biological department in the Royal Indian Engineering College at Coopers Hill, in succession to Marshall Ward, and on the closing down of that College he came to London as head of the department of botany at the Northern Polytechnic. In 1908 he joined the staff at the Imperial College of Science and Technology, first as an assistant professor, and was promoted to the chair of the technology of woods and fibres in 1911, an appointment he held to the end of his life.

Groom was the author of several books, and he contributed a number of papers, mainly on the anatomy of flowering plants, to various scientific journals, but as time went on he became more and more identified with the 'applied side' of his subject, publishing many papers in various technical journals on timber and forestry topics, as well as on the various diseases which affect wood under the numerous and diverse conditions under which it is employed. He served as a member of many committees concerned with these various matters, and his assistance was often sought by those engaged in industry, as well as by various government departments. One of his last papers was written for the Public Record Office, entitled "A Preliminary Investigation on the Mildew of Book-covers in Relation to Humidity and Temperature of the Air", and this investigation was still going on when he died. His work was recognised by his election to the fellowship of the Royal Society in 1924.

Groom's lectures at the Imperial College, especially those on timber for engineers and others interested in the technical side of the subject, were valued and were well attended. His place will not easily be filled, and as a colleague he will be held in affectionate remembrance by all who knew him.

J. B. F.

\section{Sir William Simpson, C.M.G.}

By the death of Sir William Simpson on Sept. 20 , after a few days' illness, a great exponent of tropical hygiene has passed away. William John Ritchie Simpson was born in Aberdeen, in 1855, where, after schooling in Jersey, he became a medical student, qualifying in 1876 and taking the M.D. degree four years later. He determined to choose public health as a career, and soon became the first medical officer of health of his native city and lecturer on hygiene in the University.

These posts were relinquished in 1886, when Simpson was appointed chief health officer in Calcutta, a position he held for twelve years, and thenceforward his life was devoted to the advancement of tropical hygiene and medicine. Returning to England, Simpson was elected, in 1898, professor of hygiene in King's College, London, and in $\mathbf{1 8 9 9}$ was associated with the late Sir Patrick Manson and others in the foundation of the London School of Tropical Medicine, of which he became one of the lecturers.

From now onwards Simpson was almost con-

No. 3234, VoL. 128] 